\title{
MANIFESTATION OF TEMPORAL RELATIONS IN GERMAN COMPLEX WORDS
}

\author{
Irina Kruashvili \\ Doctor of Philology, Associate Professor \\ Sokhumi State University \\ (Tbilisi, Georgia) \\ e-mail: i.kruashvili@sou.edu.ge
}

\begin{abstract}
Annotation. The aim of the article is to discuss how the temporal relations are represented in German complex words; to describe the word-building techniques and means that are actively involved in the formation of the mentioned word production meaning; to describe their formal, substantive and pragmatic features.

The paper uses several research methods, in particular, analysis of immediate constituents, transformation, substitution, and content-oriented research method. In the analysis of composites, we refer to the methods of immediate constituents, transformation and substitution, while, during the discussion of derivatives, we mainly rely on the principles of content-oriented word production.

Results of the research are as follows: determinative composites, participle word constructions, suffix and prefix derivatives participate in the construction of temporal word production meaning. Despite the different ways of generation that are based on different formal expressions, all the complex words we have discussed are grouped into a semantically closely related group. This group includes many nuances and variants of temporal relations.

Having considered the complex words expressing temporal relations in the German language, we can conclude that the determinative composite is the most productive model for the formation of such word production constructions. The suffix derivation model is also quite common to express temporal orientation. Despite the unity of content within the time category, several different segments are distinguished in word constructions, namely, they express the value/parameter observed within, before or after a certain period of time, or the even rhythm of repetitive processes, or the notation of decades.
\end{abstract}

Keywords: Temporal relations, complex words, composites, derivatives.

\section{ПРОЯВЛЕНИЕ ВРЕМЕННЫХ ОТНОШЕНИЙ В НЕМЕЦКИХ СЛОЖНЫХ СЛОВАХ}

\author{
Ирина Круашвили \\ Доктор филологии, ассоциированный профессор \\ Сухумский государственный университет \\ (Тбилиси, Грузия) \\ e-mail: 1.kruashvili@sou.edu.ge
}

\begin{abstract}
Аннотация. Цель статьи - обсудить, как временные отношения представлены в немецких сложных словах; описать словообразовательные способы и средства, которые активно участвуют в
\end{abstract}


формировании упомянутого словообразовательного значения; описать их формальные, содержательные и прагматические особенности.

В статье используется несколько методов исследования, в частности, анализ непосредственных составляющих, трансформационный метод, субституция и метод исследования, ориентированный на содержание. При анализе композитов мы ссылаемся на методы непосредственных составляющих, трансформации и подстановки, в то время как при обсуждении производных мы в основном опираемся на принципы словообразования, ориентированного на содержание.

Результаты исследования заключаются в следующем: определительные композиты, причастные словообразовательные конструкции, суффиксальные и префиксные производные участвуют в построении темпорального словообразовательного значения. Несмотря на различные способы производства, основанные на разных формальных выражениях, все сложные слова, которые мы обсуждали, сгруппированы в семантически тесно связанную группу. Эта группа включает в себя множество нюансов и вариантов временных отношений.

Рассмотрев сложные слова, выражающие временные отношения в немецком языке, можно сделать вывод, что детерминативный композит является наиболее продуктивной моделью для образования таких словообразовательных конструкций. Модель суффиксальной деривации также довольно распространена для выражения временной ориентации. Несмотря на единство содержания в категории времени, в словообразовательных конструкциях выделяются несколько различных сегментов, а именно, они выражают единицу, наблюдаемую в течение, до или после определенного периода времени, или равномерный ритм повторяющихся процессов, а также обозначения десятилетий.

Ключевые слова: Временные отношения, сложные слова, композиты, производные.

\section{INTRODUCTION}

Temporal relations within the process of word production are most clearly manifested in composites and derivatives. We therefore consider these complex words.

In many old grammar textbooks we encounter the notion that semantic relations between the constituents of a composite are much more complex than with an attribute. Later this view of old scholars changed, and linguists tried to reduce general determinative relations to several basic types. One of them is the temporal relation, which can be expressed by different compositional models.

Among derivational models, temporal word production meaning is most often represented in prefix and suffix derivatives. It should be noted, however, that not only German but also foreign (borrowed) wordbuilding affixes are characterized by considerable productivity.

\section{REVIEW OF THE ISSUE}

Growing communication needs require the constant, uninterrupted enrichment of the human vocabulary. With the development of society, the language also develops, almost all its aspects change, especially the lexical store. There are several ways to enrich the lexics of a language. One of them is word production. Each language has its own word-building system and languages differ from each other in ways and means of word production. The word-building system is characterized by well-established patterns that have been extensively studied by scientists for several decades. Among the scholars who have made a particularly great contribution to the study of the structural-semantic aspects of word production and upon whose papers we rely in the present article, we should mention W. Fleischer, I. Bartz, L. Weisgerber, I. Kuhnhold, O. Putzer, H. Wellmann, H. Elsen et al. 


\section{METHODS OF RESEARCH}

We use several methods for research that differ one from another, and the adaptation of which is highly practical and convenient for composites and derivatives. In particular, the research methods that we use are: analysis of immediate constituents, transformation, substitution, and content-oriented research methods. These methods have been used successfully since the last century to describe various levels of the German language system, among the others, in the task of determination of the patterns/generalities of word production.

\section{RESULTS AND DISCUSSION}

Temporal relations are most clearly manifested in determinative composites. In the nominal sphere, that is, when considering nouns and adjectives, in the case of the substantive first constituent, the syntagm-intern semantic relations are most clearly seen when being transformed into semantically equivalent syntactic equation. Only motivated word-building structures can be transformed in this way. In addition, to the equivalent syntactic comprehension, there are added relational words (conjunctions, prepositions, etc.) omitted in the composite. E.g., Herbstabfischen - Abfischen im Herbst, sommertrocken - trocken wie im Sommer, Achtstundentag - acht Stunden währender Arbeitstag.

Substantive adjectives are equivalent to prepositional groups, The function of which is to convey the content of the main substantive or adjectival word with more precision.

In nominal compositions, which have a noun as the first immediate constituent, the temporal relations are manifested as follows: Morgengymnastik - morgendliche Gymnastik / Gymnastik, die man am Morgen macht; morgenmüde - jemand ist am Morgen müde.

In periphrasis we have the verb sein and the temporal prepositions: in, an, während or nach. The first immediate constituent expresses a certain moment of time. It is exactly this moment where the event, mentioned in the second constituent, takes place. For example: nachmittagsstiller Platz - Platz, der am Nachmittag still ist; dämmerungsaktive Schlange - Schlange, die in der Dämmerung aktiv ist. Thus: nachtaktiv, tagesaktuell. Nachtblind is considered to be a lexicalized word, which can be interpreted in the following way: unfähig, bei Dunkelheit etwas zu sehen.

Compositions of temporal meanings are sometimes very close to causal constructs or the wordbuilding constructions expressing the cause. For example, frühlingsnärrischer Pudel can be understood as a composite of temporal wordbuilding semantics: Pudel, der im Frühling närrisch ist, and as a composite of causal wordbuilding semantics: Pudel, der närrisch ist, weil Frühling ist. This is especially true for the formations that have the component -alters- as the first immediate constituent. For instance, altersmorsche Sänfte, altersmüde Beine, altersmürbe Garderobe, altersprächtige Gestalt (Pümpel-Mader/GassnerKoch/Wellmann 1992, 130). The words abendfeucht and abendrot can also have double interpretations: abendfeuchter Park - Park, der am Abend feucht ist (temporal sema); Park, der vom Abendtau feucht ist (causal sema) (ibid).

The absolute majority of the composites of temporal world building compositions have the marking of time as the first direct constituent. E.g., Monatsplan, Tagesfahrt, Winterferien, novemberöde, weihnachtsweiß. The second direct constituent can express color (Morgenrot, Abendrot, winterweiß), physical state (abendmüde, nachtblind, tagblind, winterfit), plants or animals (Frühlingsblume, Stundenblume, Dämmerungsschwalbe), or other abstract units (Nachtleben, Septemberende, Märzwind, Jetztzeit, sekundenlang, sommerwarm).

When considering nominal word production, a modification is sometimes found, which implies alteration of the lexical meaning of a word through the word production process within the same part of speech and the same class of notations. The lexeme acquires an additional semantic nuance as a result of the 
word production process, and a word is formed that has a more precise, specific meaning than the original unit, for example, Aprilwetter - ,unbeständig wie im April“ (Duden Grammarik 682). Although the first immediate constituent expresses the data of time, namely, the name of the month, the whole word-building construct does not simply mean "April weather" but means "unstable, mostly cool weather with sudden, rapid alternation of heavy rain and light, as often happens in April." (Duden Onlinewörterbuch).

In substantive composites, the adjective as the first immediate constituent is relatively seldom found. In this case the noun is determined by expressing a temporal relation by some quantity or property, e.g. Frühbarock, Frühsommer, Spätherbst, Spätwinter.

Adjectives are also rare as the first direct constituents in adjectival composites, e.g. frühreif, frühklug, spätreif, frühinvalid. Frühreifer Junge - Junge, der früh/vorzeitig reif ist. In construction ewig-warme Sonne, the value expressed by the first constituent characterizes the state named by the second constituent as existing witout a temporal border: ewig-warme Sonne - Sonne, die ewig-warm/ewig/immerwährend warm ist (Pümpel-Mader/Gassner-Koch/Wellmann 1992, 133).

If in an adjectival composite an adjectival main word is itself a complex one that already contains a suffixed linguistic sign, e.g., kleinbürgerlich/großbürgerlich, kleinstädtisch/großstädtisch, then it is surely impossible to be said that the above-mentioned word-building construction is a composite consisting of two adjectives (klein + bürgerlich) or a suffixed derivative of a nominal composite (Kleinbürger + -lich).

The first immediate constituent in a nominal composite may be the root of a verb. In this case, the second immediate constituent gives us the period of time, during which the action expressed by the verb takes place: Backtag, Sendetermin, Sterbestunde, Bedenkzeit. Rarely can we find the adjective as the first constituent. The most commonly used adjective is sofort, which produces columns, e.g. Sofortrabatt, Soforthilfe, Sofortaktion, Soforteinsatz, Sofortmaßnahme.

The first immediate constituent may be prepositional. Here we are mainly talking about prepositions that are also used as adverbs and are often found in conjunction with verbs, e.g., vor, nach, zwischen. Vor expresses an event or circumstance that precedes another occurrence in temporal terms: Vorabend $=$ Abend vor einem Ereignis. Similar formations are: Vorfreude, Vorgefühl, Vorgeschmack. The moment of precedence is emphasized in the words: Vorarbeit, Vorgespräch. Nach expresses the state occurring after a certain event in terms of time: Nachmittag - Zeit nach dem Mittag. It is a kind of antonym of the preposition: Vorstrafe - Nachstrafe. Zwischen expresses the temporal space between two values: Zwischenzeit, Zwischenprüfung, Zwischenakt.

A temporal sema is represented in participle word-building constructs, too. They are interesting insofar as they combine syntactic expressions into one word. In the word-constructions with participle there are still revealed signs of syntagma and there are also preserved the elements of flection. Thus, it is possible to combine them in the class of Zusammenrückung (non lexicalized compound). Such formations arose as a result of a noun or adjective being in close proximity to a participle construction, e.g. preisgesenkt(e Waren) - im Preis gesenkt(e Waren). In them, one of their immediate constituents can be found in both, Partizip I and Partizip II.

Participle formations with temporal word production can express a certain period or duration of time. E.g., sommerblühend - im Sommer blühend; kurzzeiterhitzt - etwas, das für kurze Zeit erhitzt wird; herbstentlaubte Wälder - Wälder, die im Herbst entlaubt sind; frischgepflücktes Gänseblümchen Gänseblümchen, das frisch gepflückt ist/eben erst gepflückt (Pümpel-Mader/Gassner-Koch/Wellmann 1992, 210). The following productions also include the temporal sema: nachtschlafend, frischbereitetes Kartoffelpüree, neugeborenes Kind, niegeöffnete Fenster.

The columns are produced by the first constituents: frisch-, neu-, lang-. E.g., frischgewaschen, frischgestrichen, frischgebacken, neubearbeitet, neugeboren, langgehegt, langgestreckt, langgezogen, neugeschaffen, neuverheiratet.

We should discuss such an event in German word production as Zusammenbildung. The mentioned term is mainly used to refer to formations consisting of three members and having an ambivalent word- 
building structure, in which it is difficult to determine inambiguously whether we are dealing with composition or derivation. For example, the word production construction Schwarzfahrer is subject to two interpretations: 1. Derivative derived from the verb schwarzfahren; 2 . The composite consisting of the words Fahrer and schwarz. As we can see, the term Zusammenbildung cannot solve the existing problem. That is why Glück/Rödel consider the use of this term to be expedient only in cases where neither composition nor derivation is unambiguously represented. For example, the word production construction mehrgliedrig is not a derivative because there is no such derivation base ${ }^{*}$ Mehrglied. It is not a composite either, as there are no compositional members such as *Mehrglied and *gliedrig. In this case, we have a derivative derived from the syntagma, which simultaneously reveals the distinctive features of both the composite and the derivative (Glück/Rödel 2016, 789). Hence, Zusammenbildung creates a kind of transitional boundary between composition and derivation. This is a word production construction created according to the derivation pattern, but unlike derivation, here the suffix is attached not to a free morpheme, but only to a syntactic compound: diesjährig $=$ dies Jahr + -ig. The mentioned term is divergently discussed in the German linguistics. W. Fleischer / I. Barz consider such word-building constructions as explicit derivatives and reject the term Zusammenbildung (Fleischer/Barz 2012, 86). They substantiate this opinion with the fact that the basis of such word-building structures is a syntagma, which is appended with a derivative suffix. Despite this, it is still advisable to distinguish the word-building constructions, which have similar structures, under the mentioned status (We discuss as explicit derivatives such word-building constructions, the basis of which is not a syntagma but a free morpheme) (Kruashvili 2018, 11). The temporal meaning in word production is realized in similar types of formations as follows: einwöchig - eine Woche + -ig. The same pattern is observed in: zweistündig, fünftägig, dreimonatig, zehnminütig, letztjährig, kurzfristig, langlebig. It is possible to encounter the formations with the suffix -er: Frühaufsteher $=$ früh aufstehen + -er.

Apart from the above-mentioned, temporal relations are expressed in the German suffix and prefix derivatives. Both German and foreign (borrowed) affixes participate in the construction of the mentioned word production meaning.

The suffix -er is used to produce adjectives from numerals: die neunziger Jahre, die fünfziger Jahre. Such word-building constructions denote decades and thus, the root word is a rounded numeral. Denominations of decades with -er suffix can be expressed as a temporal segment, because they, in this way or another, concern years, time. There also occur adjectival derivatives with -er suffix that have been turned into nouns: ein Herr in den Sechzigern; eine Dame Ende der Zwanziger; Er war ein Dreißiger.

The suffix -ig is one of the most productive suffixes in the German language. It is related to the substantive, verbal, adjectival, adverbial bases and takes part in the formation of many word production meanings. Among the derivatives with suffix -er, word constructions derived from temporal verbs, such as einstig, nachherig, seitherig, vorig, occupy a large place. The adverbs become flectional and the respective derivatives are used as attributes. There occurs no semantic change: baldige Genesung, sofortige Wirkung, gestriges Ergebnis, damalige Zustände, morgige Sitzung. If there is the last consonant $-s$ in the adjective base, it is eliminated before the suffix -ig : damals - damalig, jeweils - jeweilig. The base can undergo other changes, too, in particular, can reduce the vowel -e : heute - heutig, morgen-morgig. The basis is the noun in the words montägig, samstägig, mittägig, nachmittägig.

The suffix -lich is related to nouns, verbs, adjectives and takes part in many forms of word production (cf. Weisgerber 1971: 218). With it, there is very common to produce formations with a substantive base, which can be both a symplex and a construction (composite, suffix or prefix derivative). Temporal relations are expressed in the derivatives with -lich suffix, the basic component of which is a noun. In this case, the lich suffix expresses the even rhythm of the repetitive processes: täglich, monatlich, wöchentlich, jährlich, minütlich, stündlich. With the same base, the suffix -ig is sometimes found next to -lich suffix, but in parallel formations a semantic differentiation is observed: zeitlicher Ablauf - "a temporal process", zeitig aufstehen "Getting up on time". 
What about prefixes, in order to express temporary relationships, there are used the prefixes post- and prä-, these two being in oppositional relations with each other, as well as the prefix über-.

The prefix post- originates from Latin and means "posterior to, afterwards". It is used in nouns, adjectives and verbs to denote such events that develop after a certain period, phase, etc.: Postmoderne, postembryonal, postdatieren (Elsen 2011, 230). The prefix post- is the antonym of the prefix pre-: postglazial, postmortal, postnatal, posttraumatisch. Constructions with the prefix post- are mainly used in a special field lexics: das postindustrielle Zeitalter, die postmoderne Architektur, eine postoperative Behandlung.

The prefix prä- also comes from Latin and means "before." It shows that some feature is fixed before a certain moment or a certain event. It occurs mainly with the suffix derivatives with foreign roots, the basic word can be a noun, adjective or verb: Präexistenz, Prämeditation, prämortal, präfabrizieren, präklusiv, präoperativ, präglazial, pränatal. Constructions with the prefix prä- are common for a terminological vocabulary: ein präembryonaler Zustand, eine prärevolutionäre Lage, das präkolumbische Amerika, die prähistorische Zeit.

The prefix über-, among others, takes part in the formation of temporal word production meanings in the fields of verb. This group includes verbs with separable prefixes such as: überdauern, überleben, überstehen. The named verbs have a verbal basis, however, there are word production constructions that have a noun as a base: überwintern, übernachten.

There are a number of creative and original formations among word constructions with temporal meaning that writers skillfully use to express their individual style in their works. During this process, rules of interconnection of constituents as well as derivation restrictions are often violated, but, as a result, we get expressive occasionalisms, the interpretation of which in the context is mostly easy and the acquaintance with which surprises and delights the reader. Here are a few examples: Sonntagabendpublikum (Haratischwili), Blütenfrühling, Erntesommer, Schneewinter (Korschunow), Augen wie ein Märzkater (Korschunow), ein paar kleine Morgenwolken (Frisch), ein schwarzes Vorkriegskleid (Korschunow), winterlangweilige Farben (Höllerer), winterkahle Pflanzen (O. Strittmatter), Märzenskind, Schmerzenskind (Bienek), Ich fahre zurück in die Kinderzeit ... Ferienfarm meiner Kindheit (Harig), Leute glotzten mich morgenblöd an (Knef). The philosopher M. Heidegger interestingly uses words in a philosophical context in his works, for example, Lang ist die dürftige Zeit der Weltnacht. ...Vielleicht wird die Weltzeit jetzt vollständig zu der durftigen Zeit (Heidegger).

\section{CONCLUSION}

We have analyzed up to 120 complex words expressing temporal relations. Although these constructions are grouped within a single word production meaning, there is presumed a very wide spectrum within them. In such composites, one of the immediate constituents expresses any particular period of time that defines, determines the second constituent. Among them, there often occur denominations of seasons, intervals of day/night and other temporal categories.

Determinant composites, the first constituent of which is represented by a noun, are especially productive. In derivatives with the suffix -lich, the respective constructs denote an even rhythm of the processes; derivatives with the suffix -er convey the meaning of decades, formations with the prefix präshow the features fixed before a certain moment of time, and those with the prefix post-, those registered after a certain period of phase. Accordingly, basic components are also different. In derivatives with the suffix -ig, the basic word is represented by an adverb, in derivatives with the suffix -er, by a numeral; the suffix -lich is represented by a substantive basis, and in the constructions with prefixes prä- and post-, the basic word formed by a noun, adjective or verb. 


\section{LIST OF REFERENCES}

Duden (2006). in 12 Bänden. Die Grammatik. Bd. 4., Mannheim et. Al.

Duden (2015). Deutsches Universalwörterbuch. 8. Auflage. Dudenverlag. Berlin.

Elsen, H. (2011). Grundzüge der Morphologie des Deutschen. Walter de Gruyter. Berlin/Boston.

Fleischer, W./Barz, I. (2012). Wortbildung der deutschen Gegenwartssprache. De Gruyter. Berlin/Boston.

Glück, H./Rödel, M. (2016). Metzler Lexikon Sprache. 5. Auflage. J. B. Metzler Verlag. Stuttgart.

Kruashvili, I. (2018). Functions of Word Building Constructions in the literary text (On the material obtained in the German language). In: "Global World". Scientific anthology. Volume 3-4. P. 6-13.

https://www.slideshare.net/nadiavuytaluk/global-world-2018

Muthmann, G. (2011). Rückläufiges Deutsches Wörterbuch. De Gruyter.

Pümpel-Mader, M./Gassner-Koch, E./Wellmann, H. (1992): Deutsche Wortbildung. Typen und Tendenzen in der Gegenwartssprache. 5. Hauptteil. Adjektivkomposita und Partizipialbildungen. Berlin, New-Jork.

Wahrig (2008). Deutsches Wörterbuch. Hg. von R. Wahrig-Burfeind. Bertelsmann. Gütersloh/München.

Weisgerber, L. (1971). Grundzüge der inhaltbezogenen Grammatik. Düsseldorf.

https://www.duden.de/woerterbuch Duden Onlinewörterbuch [am 15.09.2021].

\section{For citation:}

Kruashvili, I (2021) MANIFESTATION OF TEMPORAL RELATIONS IN GERMAN COMPLEX WORDS // International Scientific-Pedagogical Organization of Philologists “WEST-EAST " (ISPOP). Scientific Journal WESTEAST. Vol 6 N1 (October, 2021). pp. 22-28. https://doi.org/10.33739/2587-5434-2021-6-1-22-28

\section{Для цитирования:}

КрУашвиЛи, И. (2021) ПРОЯВЛЕНИЕ ВРЕМЕННЫХ ОТНОШЕНИЙ В НЕМЕЦКИХ СЛОЖНЫХ СЛОВАХ // International Scientific-Pedagogical Organization of Philologists "WEST-EAST " (ISPOP). Scientific Journal WESTEAST. Vol 6 N1 (October, 2021). C. 22-28. https://doi.org/10.33739/2587-5434-2021-6-1-22-28

Information about the author: Irina Kruashvili - $\mathrm{PhD}$, associate Professor for German linguistics at Sokhumi State University (Tbilisi), Scholarship holder of the DAAD and the Goethe-Institut, member of the Senate of Sokhumi State University, member of the German Teachers ' Association in Georgia (DVG), member of the International Association for German Studies (IVG), author of more than 50 scientific publications in German, English, Russian and Georgian. (Georgia).

e-mail: i.kruashvili@sou.edu.ge

Сведения об авторе: Ирина Круашвили - Доктор филологии, ассоциированный профессор Сухумского Государственного Университета (Тбилиси), стипендиат DAAD и Гете-Института, член Сената при Сухумском Государственном Университете, член Ассоциации Учителей Немецкого Языка в Грузии (DVG), член Международной Ассоциации Германистики (IVG), автор более 50 научных публикаций на немецком, английском, русском и грузинском языках. (Грузия).

e-mail: i.kruashvili@sou.edu.ge

Manuscript received: 08/15/2021

Accepted for publication: $09 / 15 / 2021$

Рукопись получена: 08/15/2021

Принята к печати: 09/15/2021

International Scientific-Pedagogical Organization of Philologists "West-East" ISPOP

SCIENTIFIC JOURNAL " WEST-EAST"

ISSN (print) - 2587-5434 ISSN (online) - 2587-5523

Index in SIS ID:7515
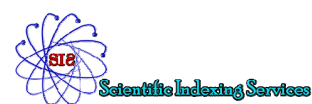